\title{
Evaluasi Penentuan Tarif Kamar Hotel Dengan Menerapkan Metode Activity Based Costing Pada Hotel Zenith Kendari
}

\author{
Oleh \\ Erwin Hadisantoso ${ }^{1}$, Ishak Awaluddin ${ }^{2}$, Mira Nuka ${ }^{3}$ \\ E-mail: miranuka683@gmail.com
}

\begin{abstract}
This study aims to determine how the calculation of the Activity Based Costing method in calculating Zenith Hotel room rental rates and to determine the calculation of hotel room rental rates with the Activity Based Costing method and the rates set by the company. The type of data in this research is quantitative data and qualitative data. Sources of data in this study are primary data and secondary data. Data collection techniques in this study were interviews and documentation. Analysis of the data used is descriptive analysis.

The results of this study indicate that by using the Activity Based Costing method, it is known that the rates for Superior room types are Rp.220.854,00. For Deluxe rooms Rp.302.904,00. And for the Junior Suite Rp.422.904,00. There is a difference between calculating rates using the Activity Based Costing method and those determined by the company, namely the Activity Based Costing method gives a lower yield by the difference for the Superior room type of Rp.79,146.00, for the Deluxe room type of Rp.47,096.00 and for the junior suite Rp.127,146.00. In this study still has shortcomings in file retrieval because the hotel did not provide detailed cost details but only gave the overall results file. It is expected that further researchers should examine the place or company that can provide more detailed cost information.
\end{abstract}

Keywords: Activity, Cost Driver, Activity Based Costng

\section{PENDAHULUAN}

Persaingan yang terjadi diera global ini bukan hanya dalam bisnis manufaktur maupun bisnis perdagangan, tetapi juga dalam bisnis pelayanan jasa yang bergerak dibidang pariwisata dan perhotelan. Dimana saat ini jasa perhotelan mengalami perkembangan yang cukup pesat, sehingga muncul banyak pesaing dan semakin ketat persaingan antar hotel. Setiap perusahaan harus memiliki strategi dan inovasi agar mampu bersaing dalam arus bisnis. Kondisi ini menuntut para pengembang atau pelaku usaha untuk fokus menjamin kualitas dan pelayanan serta penetapan harga yang terjangkau. Perusahaan harus dapat secara efisien dan efektif menentukan harga yang sesuai dengan kualitas dan pelayanan yang mampu bertahan melawan pesaing. Tidak banyak orang yang memahami bahwa harga pokok produk dan jasa merupakan refleksi kemampuan suatu organisasi dalam memproduksi barang dan jasa. Semakin tinggi kemampuan mengelola biaya (cost), maka akan semakin baik produk dan jasa yang ditawarkan pada pelanggan baik dari sisi harga maupun kualitas.

Sistem ABC dapat menyediakan informasi perhitungan biaya yang lebih baik dan dapat membantu manajemen mengelola perusahaan secara efisien serta memperoleh pemahaman yang lebih baik atas keunggulan, kekuatan, dan kelemahan perusahaan. Metode ini dapat menyajikan informasi harga pokok produk atau jasa secara cermat dan akurat bagi kepentingan manajemen. Konsep sistem Activity Based Costing merupakan alternatif solusi yang ditempuh oleh 
perusahaan untuk mendapatkan informasi akuntansi yang relevan dalam pengambilan keputusan atas penetapan harga pokok dan penetapan harga jual yang lebih tepat. Dari berbagai penelitian penerapan sistem ABC diyakini dapat diterapkan dalam penentuan tarif kamar di berbagai pelayanan jasa, salah satunya dibidang perhotelan. Dalam dunia bisnis perhotelan masih banyak menerapkan sistem konvesional atau tradiosional. Salah satunya bisnis perhotelan di Kota Kendari yakni Hotel Zenith. Dengan melihat karakteristik spesifikasi jenis kamar, pelayanan, serta potensi persaingan dari kompetitor maka salah satu cara yang dilakukan Hotel Zenith dalam upaya meningkatkan efisiensi biayanya adalah dengan menentukan harga pokok produk/jasa secara tepat. Cara yang ditempuh perusahaan untuk menentukan harga pokok produksi/jasa secara akurat dan efektif adalah dengan menggunakan konsep Activity Based Costing.

Hotel Zenith dalam penentuan tarif kamar masih menggunakan system konvesional sehingga dalam menentukan tarif kamar tidak menghitung biaya yang terjadi tetapi hanya penjualan perkiraan dari tarif hotel sejenis. Penentuan tarif sewa kamar pada hotel zenith setiap tahunnya memiliki perubahan di budget atau anggaran dan munculnya hotel-hotel baru yang sejenis berpengaruh pada penentuan tarif kamar sehingga harga pokok pada kamar tidak dapat diprediksi dan penggangaran dilakukan selama satu tahun sekali. Adapun tarif sewa masingmasing kamar pada Hotel Zenith Kendari dapat dilihat pada tabel berikut berikut :

Tabel 1.1 Tarif masing-masing kamar pada Hotel Zenith Kendari

\begin{tabular}{|l|l|l|l|}
\hline \multirow{2}{*}{ Tipe Kamar } & \multicolumn{3}{|c|}{ Tarif Sewa (perhari) } \\
\cline { 2 - 4 } & \multicolumn{1}{|c|}{$\mathbf{2 0 1 6}$} & $\mathbf{2 0 1 7}$ & $\mathbf{2 0 1 8}$ \\
\hline Superior & $\mathrm{Rp} .285,000$ & $\mathrm{Rp} .325 .000$ & $\mathrm{Rp} .300 .000$ \\
\hline Deluxe & $\mathrm{Rp} .330 .000$ & $\mathrm{Rp} .355 .000$ & $\mathrm{Rp} .350 .000$ \\
\hline Junior Suite & $\mathrm{Rp} .550 .000$ & $\mathrm{Rp} .533 .000$ & $\mathrm{Rp} .550 .000$ \\
\hline
\end{tabular}

Sumber : Data hotel zenith kendari

Berdasarkan tabel diatas menunjukan bahwa tarif sewa kamar perhari ditahun 2016 untuk jenis kamar Superior sebesar Rp.285.000, Deluxe sebesar Rp.330.000 dan Junior Suite sebesar Rp.550.000 dan mengalami peningkatan tarif ditahun 2017 untuk jenis kamar superior sebesar Rp 325.000, dan Deluxe sebesar Rp.355.000 sedangkan untuk jenis kamar Junior Suite mengalami penurunan sebesarRp. 533.000. Selanjutnya ditahun 2018 tarif sewa kamar mengalami penurunan untuk jenis kamar Superior sebesar Rp.300.000 dan untuk jenis kamar Deluxe sebesar Rp.350.000 sedangkan untuk jenis kamar Junior Suite mengalami peningkatan sebesar Rp.550.000.

Berdasarkan latar belakang di atas, maka dalam penelitian ini penulis tertarik untuk menyusun skripsi dengan judul " Evaluasi Penentuan Tarif Hotel Dengan Menerapkan Metode Activity Based Costing Pada Hotel Zenith Kota Kendari”.

\subsection{Biaya}

\section{KAJIAN PUSTAKA}

Biaya mempunyai berbagai macam definisi tergantung pada tingkat kegunaannya. Biaya dapat diartikan sebagai nilai yang harus kita keluarkan untuk memperoleh suatu barang. Menurut Mulyadi (2015:8) pengertian biaya adalah pengorbanan sumber ekonomi, yang diukur dalam satuan uang, yang telah terjadi atau yang kemungkinan akan terjadi untuk tujuan tertentu. Adapun Mursyidi (2014:14) mendefinisikan biaya (cost) adalah sebagai suatu pengorbanan yang dapat mengurangi kas atau harta lain untuk mencapai tujuan, baik yang dapat dibebankan saat ini maupun di masa yang akan datang.

Hansen dan Mowen (2012:47) menyatakan bahwa biaya adalah kas atau nilai ekuivalen kas yang di korbankan untuk mendapatkan barang atau jasa yang diharapkan memberi manfaat 
saat ini atau di masa yang akan datang bagi organisasi. Di katakana sebagai ekuivalen kas karena sumber non kas dapat di tukar dengan barang atau jasa yang di inginkan. Jadi, kita dapat menganggap biaya sebagai ukuran dollar dari sumber daya yang digunakan untuk mencapai keuntungan tertentu.

\subsection{Penentuan Tarif}

Supriyono (2010:350) mendefinisikan tarif adalah sejumlah moneter yang dibebankan atas barang atau jasa yang dijual atau diserahkan kepada pembeli atau pelanggan. Untuk menentukan tarif, biasanya manajemen mempertimbangkan beberapa faktor yang mempengaruhi baik faktor biaya maupun bukan biaya, yaitu: Biaya, khususnya biaya masa depan, Pendapatan yang diharapkan, Jenis produk jasa yang dijual, Jenis industri, Citra dan kesan masyarakat, Pengaruh pemerintah, khususnya undang-undang, keputusan, peraturan dan kebijakan pemerintah, Tindakan atau reaksi para pesaing, Tipe pasar yang dihadapi, Trend Ekonomi, Biaya manajemen, Tujuan non laba, Tanggung jawab sosial perusahaan, Tujuan perusahaan,khususnya laba dan return on investment (ROI). Dalam penentuan tarif atau harga jual produk, manajemen perlu tujuan dari penentuan tarif tersebut. Tujuan itu akan dipergunakan sebagai salah satu pedoman kerja perusahaan. Pada umumnya tujuan tersebut adalah sebagai berikut: a.Bertahan hidup (survival), Perusahaan menetapkan bertahan hidup sebagai tujuan utama, apabila menghadapi kesulitan dalam hal kelebihan kapasitas produksi, persaingan keras, atau perubahan keinginan konsumen. Untuk mempertahankan tetap berjalannya kegiatan produksi, perusahaan harus menetapkan harga yang rendah, dengan harapan akan meningkatkan permintaan. Dalam situasi demikian, laba menjadi kurang penting dibandingkan survival. b. Memaksimalkan laba jangka pendek Perusahaan memperkirakan permintaan akan biaya, dihubungkan dengan harga alternatif dan harga yang akan menghasilkan laba, arus kas, atau tingkat laba investasi maksimal. Dalam semua hal, perusahaan lebih menitikberatkan pada kemampuan keuangan yang ada dan kurang mempertimbangkan prestasi keuangan jangka pendek. c. Kepemimpinan pangsa pasar (leader of market share), Sebagian perusahaan ingin mencapai pangsa pasar yang dominan. Mereka yakin bahwa perusahaan dengan market share terbesarakan menikmati biaya terendah dan laba tertinggi dalam jangka panjang. Untuk itu, mereka menetapkan harga serendah mungkin. d. Kepemimpinan mutu produk, Perusahaan dapat memutuskan bahwa mereka ingin memiliki produk dengan mutu terbaik di pasar. Keputusan ini biasanya mengharuskan penetapan harga yang tinggi untuk menutup biaya pengendalian mutu produk serta biaya riset dan

pengembangan, e. Tujuan-tujuan lain, Misalnya mempertahankan loyalitas pelanggan Perusahaan mungkin menetapkan harga yang rendah untuk mencegah masuknya perusahaan pesaing atau dapat menetapkan harga yang sama dengan pesaing dengan tujuan untuk mempertahankan loyalitas pelanggan. Menghindari campur tangan pemerintah, menciptakan daya tarik sebuah produk, dan untuk menarik lebih banyak pelanggan.

\subsection{Activity Based Costing}

Activity Based Costing merupakan sistem yang menerapkan konsep-konsep akuntansi aktivitas untuk menghasilkan perhitungan harga pokok yang lebih akurat. Namun, dari prespektif manajerial, sistem $\mathrm{ABC}$ tidak hanya menawarkan lebih dari sekedar informasi biaya produk yang akurat akan tetapi juga menyediakan informasi tentang biaya dan kinerja dari aktivitas dan sumber daya serta dapat menelusuri biaya-biaya secara akurat ke objek biaya selain produk, misalnya pelanggan dan saluran distribusi. Perhitungan biaya berdasarkan aktivitas merupakan pendekatan perhitungan biaya yang membebankan biaya sumber daya ke objek biaya seperti produk, jasa, atau pelanggan berdasarkan aktivitas yang dilakukan untuk objek biaya tersebut.

Menurut Mulyadi (2014:40) Activity Based Costing adalah Sistem informasi biaya yang berorientasi pada penyediaan informasi lengkap tentang aktivitas untuk memungkinkan personel 
perusahaan melakukan pengolahan terhadap aktivitas. Sistem informasi ini menggunakan aktivitas sebagai basis serta pengurangan biaya dan penentuan secara akurat cost produk/jasa sebagai tujuan. Pengelolaan aktivitas ditujukan untuk mengerahkan dan mengarahkan seluruh aktivitas organisasi ke penyediaan produk/jasa bagi kepentingan pemuasan kebutuhan customer. Sedangkan Carter Usry (2009:528) menyatakan bahwa Activity Based Costing System adalah suatu sistem perhitungan biaya dimana tempat penampungan biaya overhead yang jumlahnya lebih dari satu dialokasikan menggunakan dasar yang memasukkan satu atau lebih faktor yang tidak berkaitan dengan volume (non-volume-related factor). Pengertian activity based costing yang lain juga dikemukakan oleh Siregar dkk (2014:240) Activity based costing (ABC) merupakan "metode penentuan biaya produk yang pembebanan biaya overhead berdasarkan pada aktivitas-aktivitas yang dilakukan dalam kaitannya dengan proses produksi.

Activity based costing system memfokuskan aktivitas sebagai objek biaya yang fundamental. Activity based costing system menggunakan biaya dari aktivitas sebagai dasar untuk membagikan biaya ke objek lain seperti produk, jasa, atau konsumen. Aktivitas yang terjadi di perusahaan dipengaruhi oleh penggerak biaya dari biaya-biaya yang dikeluarkan untuk aktivitas tersebut. Aktivitas adalah setiap kejadian atau transaksi yang merupakan pemicu biaya (cost driver) yakni, bertindak sebagai faktor penyebab dalam pengeluaran biaya dalam organisasi. Aktivitas aktivitas ini menjadi titik perhimpunan biaya. Dalam sistem ABC, biaya ditelusur ke aktivitas dan kemudian ke produk. Activity Based Costing System mengasumsikan bahwa aktivitas-aktivitas yang mengkonsumsi sumber daya dan bukannya produk.

Gambar 1. Konsep Dasar Activity Based Costing

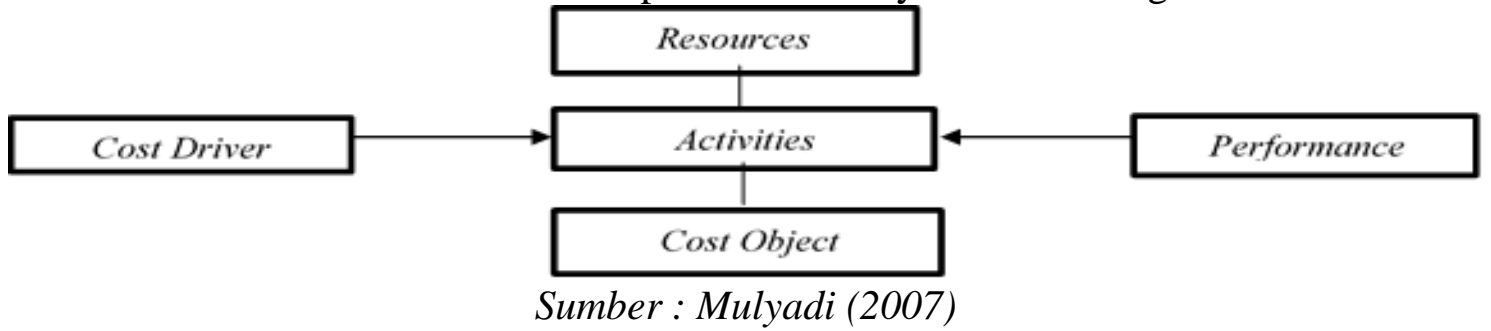

Mulyadi (2007:52) mengungkapkan dua filsafah atau keyakinan dasar yang melandasi ABC system:

a. Cost is coused

Biaya ada penyebabnya dan penyebab biaya adalah aktivitas. Dengan demikian, pemahaman yang mendalam tentang aktivitas yang menjadi penyebab timbulnya biaya akan menempatkan personel perusahaan pada posisi dapat mempengaruhi biaya. ABC system berangkat dari keyakinan dasar bahwa sumber daya menyediakan kemampuan untuk melaksanakan aktivitas, bukan sejadar menyebabkan timbulnya biaya yang harus dialokasikan.

b. The couse of cost can be managed

Penyebab terjadinya biaya (yaitu aktivitas) dapat dikelola. Melalui pengolaan terhadap aktivitas yang menjadi penyebab terjadinya biaya, personel perusahaan dapat mempengaruhi biaya. Pengelolaan terhadap aktivitas memerlukan berbagai informasi tentang aktivitas.

\subsection{Hierarki Biaya Dalam Activity Based Costing System}

Pada pembentukan kumpulan aktivitas yang berhubungan dengan aktivitas diklasifikasikan menjadi beberapa level aktivitas yaitu level unit, level batch, level produk dan level fasilitas. Pengklasifikasian aktivitas dalam beberapa level ini akan memudahkan perhitungan karena biaya aktivitas yang berkaitan dengan level yang berbeda akan menggunakan jenis Cost Driver yang berbeda. Hierarki biaya merupakan pengelompokkan biaya dalam 
berbagai kelompok biaya (cost pool) sebagai dasar pengalokasian biaya. Firdaus dan Wasilah (2009:324) memaparkan hierarki biaya dalam Activity Based Costing System yaitu : a. Biaya untuk setiap unit (output unit level) adalah sumber daya yang digunakan untuk aktivitas yang akan meningkat pada setiap unit produksi atau jasa yang dihasilkan. Dasar pengelompokan untuk level ini adalah hubungan sebab akibat setiap unit yang dihasilkan, b. Biaya untuk setiap kelompok unit tertentu (batch level) adalah sumber daya yang digunakan untuk aktivitas yang akan terkait dengan kelompok unit produk atau jasa yang dihasilkan. Dasar pengelompokan untuk level ini adalah biaya yang hubungan sebab akibat untuk setiap kelompok unit yang dihasilkan. c. Biaya untuk setiap produk/jasa tertentu (product/service sustaining level) adalah sumber daya digunaka untuk aktivitas yang menghasilkan suatu produk dan jasa. Dasar pengelompokan untuk level ini adalah biaya yang memiliki hubungan sebab akibat dengan setiap produk atau jasa yang dihasilkan. a. Biaya untuk setiap fasilitas tertentu (facility sustaining level) adalah sumber daya yang digunakan untuk aktivitas yang tidak dapat dihubungkan secara langsung dengan produk atau jasa yang dihasilkan tetapi untuk mendukung organisasi secara keseluruhan.

\subsection{Perbedaan Sistem Akuntansi Tradisional dengan Sistem Activity Based Costing}

Perbedaan antara Traditional Costingdan Activity Based Costing dapat dilihat dari tabel berikut:

Tabel 2.1 Perbedaan antara Traditional Costing dan Activity Based Costing

\begin{tabular}{|l|l|l|}
\hline Keterangan & Traditional Costing & Activity Based Costing \\
\hline Tujuan & Inventory valuation & Product costing \\
\hline Lingkup & Tahap produksi & $\begin{array}{l}\text { Tahap desain, tahap produksi, } \\
\text { dan tahap dukungan logistic }\end{array}$ \\
\hline Fokus & $\begin{array}{l}\text { Biaya bahan baku, biaya } \\
\text { tenagakerja langsung }\end{array}$ & Biaya overhead pabrik \\
\hline Periode & Periode akuntansi & Dasar hidup produk \\
\hline $\begin{array}{l}\text { Teknologi Informasi } \\
\text { yang digunakan }\end{array}$ & Metode manual & Komputer telekomunikasi \\
\hline
\end{tabular}

Sumber : Ahmad Dunia dan Wasilah, 2012

\subsection{Kerangka Pikir}

\section{Skema 2.1 Kerangka Pikir}

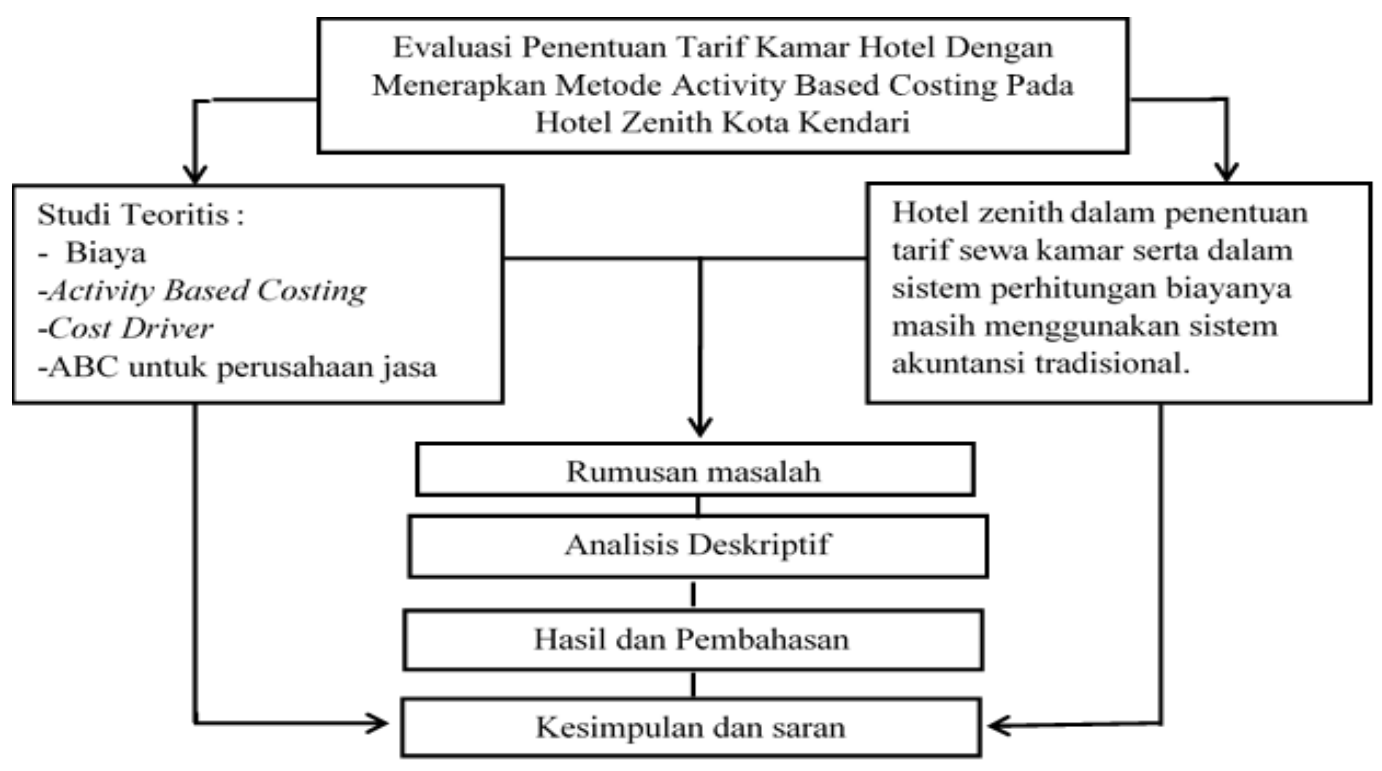




\subsection{Lokasi dan Objek Penelitian}

\section{METODE PENELITIAN}

Penelitian ini dilakukan di Hotel Zenith yang beralamat di Jl. Malik Raya No.20 Kelurahan Korumbu Kecamatan Mandonga Kendari. Objek penelitian ini adalah semua biayabiaya dan data-data yang dibutuhkan mengenai masalah yang akan diteliti.

\subsection{Jenis dan Sumber Data}

\subsubsection{Jenis Data}

a. Data Kualitatif yaitu kumpulan data yang berkaitan dengan informasi yang dinyatakan dalam bentuk lisan maupun tulisan seperti sejarah singkat, pembagian tugas dan struktur organisasi Hotel Zenith Kendari

b. Data Kuantitatif yaitu data atau informasi yang berupa angka-angka antara lain laporan biaya-biaya yang terkait, daftar tarif kamar hotel dll.

\subsubsection{Sumber Data}

Data yang digunakan dalam penelitian ini berupa :

a. Data Primer yaitu data yang diperoleh dengan melakukan interview (wawancara) langsung dengan pihak hotel mengenai data yang dibutuhkan. Data yang dibutuhkan berupa data yang berkaitan dengan pokok permasalahan dalam penelitian ini.

b. Data Sekunder yaitu data yang diperoleh dengan cara mengambil data-data yang telah didokumentasikan oleh bagian administrasi dan keuangan serta bagian yang terkait dengan penelitian ini.

\subsection{Metode Pengumpulan data}

Teknik Pengumpulan data yang dilakukan dalam penelitian ini yaitu:

a. Metode wawancara yaitu teknik pengumpulan data dengan mengadakan tanya jawab atau wawancara langsung dengan pihak hotel yang berwenang untuk mengumpulkan data mengenai objek yang diteliti.

b. Metode Dokumentasi yaitu pengambilan data yang telah didokumentasikan yang relevan dengan penelitian seperti dokumen-dokumen yang berupa tarif masing-masing kamar Hotel Zenith

\subsection{Metode Analisis Data}

Metode analisis data yang digunakan dalam penelitian ini adalah metode analisis

Deskriptif yakni memberikan penjelasan dan gambaran mengenai hasil perhitungan tarif kamar hotel padaHotel Zenith Kendari.

Adapun Langkah-langkah analisis yang dilakukan dalam penelitian ini adalah:

a. Mengidentifikasi aktivitas

b. Mengklasifikasikan biaya berdasar aktivitas kedalam berbagai aktivitas

c. mengidentifikasi cost driver

d. menentukan tarif per unit cost driver

Untuk menentukan tarif per unit dihitung dengan rumus:

Tarif per unit cost driver $=$ jumlah aktivitas $/$ Cost driver

Sumber : Hansen dan Mowen 2009

e. membebankan biaya ke produk dengan menggunakan tarif cost driver dan ukuran aktivitas yaitu:

1. Pembebanan biaya overhead dari tiap aktivitas kesetiap kamar dihitung dengan rumus sebagai berikut:

BOP yang dibebankan =tarif/unit $\mathrm{x}$ cost driver yang dipilih 
Sumber : Hansen dan Mowen 2009

2. Kemudian perhitungan tarif masing-masing tipe kamar dengan metode Activity Based Costing System dapat dihitung dengan rumus sebagai berikut:

Tarif per kamar = cost kamar + laba yang diharapkan

Sumber : Hansen dan Mowen 2009

f. Membandingkan perhitungan tarif sewa kamar hotel berdasarkan perhitungan perusahaan dengan Activity Based Costing System.

\section{HASIL PENELITIAN DAN PEMBAHASAN}

\subsection{Hasil Penelitian}

\subsubsection{Tarif Kamar Menurut Hotel Zenith}

Berdasarkan data yang diperoleh dari Hotel Zenith terdapat tiga (3) jenis kamar yang ada di Hotel Zenith yaitu Superior, Deluxe, Junior Suite. Jumlah kamar yang terjual untuk setiap kamar yang ada di Hotel Zenith pun berbeda-beda. Perhitungan harga pokok tarif sewa Hotel Zenith masih menggunakan metode tradisional yang hanya mempertimbangkan biaya yang bersifat umum. Biaya-biaya dari kegiatan yang sifatnya umum ini proses pembebananya dilakukan dengan cara alokasi. Besarnya jumlah alokasi biaya tersebut berdasarkan aktivitas per unit setiap produk dan jasa kemudian membebankan biaya ke jasa kamar hotel dengan menggunakan harga per unit cost driver terhadap total pendapatan kamar hotel. Adapun besarnya tarif untuk setiap kamar pada Hotel Zenith dapat dilihat pada tabel berikut :

Tabel 4.1 Tarif kamar Hotel Zenith Tahun 2018

\begin{tabular}{|l|l|}
\hline Jenis Kamar & Tarif Kamar (Perhari) \\
\hline Superior & Rp.300.000 \\
\hline Deluxe & Rp.350.000 \\
\hline Junior Suite & Rp.550.000 \\
\hline
\end{tabular}

Sumber : Data Hotel Zenith Kendari, 2018

Di dalam menentukan tarif kamar hotel dengan menggunakan metode ABC, diperlukan data-data seperti elemen biaya yang berhubungan langsung dengan kamar hotel dan data pendukung lainnya seperti data jumlah kamar tersedia dijual, jumlah hari hunian kamar dan luas lantai kamar hotel. Data di bawah ini merupakan data pendukung untuk perhitungan dengan menggunakan metode $\mathrm{ABC}$.

Tabel 4.2 Luas Lantai Kamar Hotel Zenith

\begin{tabular}{|l|c|}
\hline Jenis Kamar & Luas Lantai \\
\hline Superior & $16 \mathrm{~m}^{2}$ \\
\hline Deluxe & $16 \mathrm{~m}^{2}$ \\
\hline Junior Suite & $24 \mathrm{~m}^{2}$ \\
\hline
\end{tabular}

Sumber : Data Hotel Zenith Kendari, 2018

Untuk jumlah kamar tersedia untuk dijual dan jumlah hari tamu menginap disetiap jenis kamar selama tahun 2018 pada Hotel Zenith dapat di lihat pada tabel berikut

Tabel 4.3 Jumlah Kamar Tersedia Untuk dijual

\begin{tabular}{|l|c|l|}
\hline \multicolumn{1}{|c|}{ Jenis Kamar } & Jumlah Kamar (1) & $\begin{array}{c}\text { Jumlah Kamar Setahun } \\
\text { (1) X 365 Hari }\end{array}$ \\
\hline Superior & 30 & 10950 \\
\hline Deluxe & 47 & 17155 \\
\hline Junior Suite & 8 & 2920 \\
\hline Jumlah & $\mathbf{8 5}$ & $\mathbf{3 1 0 2 5}$ \\
\hline
\end{tabular}

Sumber : Data Hotel Zenith Kendari, 2018 
Berdasarkan hasil tabel 4.3 diatas menunjukan bahwa jumlah kamar tersedia untuk dijual tahun 2018 paling banyak pada kamar dengan tipe deluxe yaitu sebanyak 17.155 kamar dalam setahun. Untuk jumlah hari hunia kamar Hotel Zenith selama 2018 dapat dilihat pada tabel berikut :

Tabel 4.4 Jumlah Hari Hunian Kamar Hotel Zenith Tahun 2018

\begin{tabular}{|l|c|c|c|}
\hline \multicolumn{1}{|c|}{ Bulan } & Superior & Deluxe & junior suite \\
\hline Januari & 284 & 326 & 23 \\
\hline Februari & 294 & 314 & 27 \\
\hline Maret & 294 & 306 & 34 \\
\hline April & 277 & 352 & 57 \\
\hline Mei & 227 & 294 & 41 \\
\hline Juni & 164 & 123 & 5 \\
\hline Juli & 303 & 333 & 18 \\
\hline Agustus & 290 & 380 & 48 \\
\hline September & 312 & 365 & 49 \\
\hline Oktober & 308 & 338 & 27 \\
\hline November & 286 & 394 & 50 \\
\hline Desember & 385 & 407 & 53 \\
\hline Jumlah & $\mathbf{3 4 2 4}$ & $\mathbf{3 9 3 2}$ & $\mathbf{4 3 2}$ \\
\hline
\end{tabular}

Sumber data : Hotel Zenith 2018

Berdasarkan tabel 4.4 atas perhitungan dari proses pembebanan biaya dan penentuan harga jual jasa untuk masing-masing jenis kamar pada Hotel Zenith dapat dijelaskan melalui perhitungan sebagai berikut.

a. Tingkat pengisian kamar atau tingkat hunian kamar penginapanmasing-masing jenis kamar (occupancy rate) selama tahun 2018.

Tabel 4.5 Occupancy Rate Hotel Zenith 2018

\begin{tabular}{|l|r|r|r|}
\hline Jenis Kamar & \multicolumn{2}{|c|}{$\begin{array}{c}\text { Jumlah kamar } \\
\text { terjual } \\
(\mathbf{1})\end{array}$} & \multicolumn{2}{|c|}{$\begin{array}{c}\text { Jumlah } \\
\text { kamar tersedia } \\
(\mathbf{2})\end{array}$} & $\begin{array}{l}\text { Occupancy Rate } \\
\mathbf{( 1 )}: \mathbf{( 2 )} \mathbf{x} \mathbf{1 0 0 \%}\end{array}$ \\
\hline Superior & 3424 & 10950 & $31,27 \%$ \\
\hline Deluxe & 3932 & 17155 & $22,92 \%$ \\
\hline Junior Suite & 432 & 2920 & $14,79 \%$ \\
\hline Jumlah & $\mathbf{7 7 8 8}$ & $\mathbf{3 1 0 2 5}$ & $\mathbf{6 8 , 9 8 \%}$ \\
\hline
\end{tabular}

Sumber data : Hotel Zenith 2018

b. Penjualan jasa kamar hotel dari masing-masing jenis kamar selama tahun 2018

Tabel 4.6 Pendapatan Penjualan Jasa Kamar Hotel Zenith Tahun 2018

\begin{tabular}{|l|r|r|r|}
\hline Jenis Kamar & $\begin{array}{c}\text { Jumlah } \\
\text { kamar } \\
\text { terjual } \\
(\mathbf{1})\end{array}$ & $\begin{array}{l}\text { Tarif } \\
\text { Kamar }\end{array}$ & $\begin{array}{c}\text { Pendapatan Jasa Kamar } \\
\text { (Rp) } \\
(\mathbf{1}) \mathbf{x}(\mathbf{2})\end{array}$ \\
\hline Superior & 3424 & 300.000 & 1.027 .200 .000 \\
\hline Deluxe & 3932 & 350.000 & 1.376 .200 .000 \\
\hline Junior Suite & 432 & 550.000 & 237.600 .000 \\
\hline Jumlah & & & $\mathbf{2 . 6 4 1 . 0 0 0 . 0 0 0}$ \\
\hline
\end{tabular}

Sumber data : Hotel Zenith 2018 
c. Persentase pendapatan dari masing-masing jenis kamar hotel terhadap pendapatan dari penjualan jenis kamar secara keseluruhan selama tahun 2018.

Tabel 4.7 Persentase Pendapatan Penjualan Jasa Kamar Hotel Zenith Tahun 2018

\begin{tabular}{|c|c|c|c|}
\hline Jenis Kamar & $\begin{array}{l}\text { Pendapatan } \\
\text { Jasa Kamar } \\
(\mathbf{R p})(\mathbf{1})\end{array}$ & $\begin{array}{l}\text { Pendapatan } \\
\text { Jasa Kamar } \\
(\operatorname{Rp}(2)\end{array}$ & $\begin{array}{c}\text { Persentase } \\
\text { Pendapatan } \\
(1):(2) \times 100 \%\end{array}$ \\
\hline Superior & 1.027 .200 .000 & \multirow{3}{*}{2.641 .000 .000} & $38,89 \%$ \\
\hline Deluxe & 1.376 .200 .000 & & $52,10 \%$ \\
\hline Junior Suite & 237.600 .000 & & $8,99 \%$ \\
\hline JumlVah & 2.641 .000 .000 & 2.641 .000 .000 & $100 \%$ \\
\hline
\end{tabular}

Sumber data: Hotel Zenith 2018

\subsubsection{Perhitungan Sewa Tarif Kamar Dengan Metode Activity Based Costing System}

Langkah-langkah yang dilakukan dalam menghitung tarif sewa kamar atau harga pokok kamar dengan menggunakan metode Activity Based Costing (ABC) dalam penelitian ini yaitu :

1. Pengidentifikasian Aktivitas

Berdasarkan wawancara dengan pihak Hotel Zenith maka didapat aktivitas-aktivitas yang menimbulkan biaya dapat dilihat pada tabel berikut :

\section{Tabel 4.8 Daftar Aktivitas}

\begin{tabular}{|c|l|}
\hline No & \multicolumn{1}{|c|}{ Aktivitas } \\
\hline 1. & Aktivitas penginapan \\
\hline 2. & Aktivitas Laundry \\
\hline 3. & Aktivitas pemberian sarapan \\
\hline 4. & Aktivitas Listrik dan Air \\
\hline 5. & Aktivitas Telepon dan Internet \\
\hline 6. & Aktivitas Transportasi \\
\hline 7. & Aktivitas Pemeliharaan \\
\hline 8. & Aktivitas Penyusutan \\
\hline
\end{tabular}

Sumber : Data diolah

2. Pengklasifikasian biaya berdasarkan aktivitas kedalam berbagai level aktivitas

Setelah daftar aktivitas disusun selanjutnya adalah mengklasifikasikan aktivitasaktivitas tersebut ke dalam level aktivitas yang digolongkan dalam empat kategori yaitu : aktivitas tingkat unit, aktivitas tingkat batch, aktivitas tingkat produk dan aktivitas tingkat fasilitas dapat dilihat pada tabel berikut :

Tabel 4.9 Klasifikasi Aktivitas Berdasarkan Tingkat Aktivitas

\begin{tabular}{|l|l|}
\hline \multicolumn{1}{|c|}{ Aktivitas } & \multicolumn{1}{c|}{ Level Aktivitas } \\
\hline Aktivitas penginapan & Unit-level activity cost \\
\hline Aktivitas pemberian sarapan & Unit-level activity cost \\
\hline Aktivitas listrik dan air & Unit-level activity cost \\
\hline Aktivitas penggajian & Unit-level activity cost \\
\hline Aktivitas transportasi & Unit-level activity cost \\
\hline Aktivitas telepon dan internet & Batch-level activity cost \\
\hline Aktivitas pemasaran & Product-sustaining activity cost \\
\hline Aktivitas laundry & Fasilitas-sustaining activity cost \\
\hline Aktivitas pemeliharan & Fasilitas-sustaining activity cost \\
\hline Aktivitas penyusutan & Fasilitas-sustaining activity cost \\
\hline
\end{tabular}

Sumber : Data diolah 


\section{Pengidentifikasian cost driver}

Setelah aktivitas-aktivitas di identifikasi sesuai dengan kategorinya langkah selanjutnya adalah pengidentifikasian cost driver dari setiap aktivitas sebagai berikut :

a. Aktivitas penginapan untuk dasar pengalokasian dapat berdasarkan jumlah tamu yang menginap dan jumlah kamar terjual. Tetapi dengan mengingat bahwa biaya-biaya meningkat jika jumlah kamar terjual, maka dapat dijadikan cost driver adalah jumlah kamar terjual.

b. Aktivitas laundry meliputi pencucian handuk, seprei, sarung bantal, dan selimut. Untuk dasar pengalokasian dapat berdasarkan jumlah kamar tersedia dan jumlah kamar terjual. Tetapi pencucian tersebut hanya dilakukan setelah kamar terjual, maka dapat dijadikan cost driver adalah jumlah kamar terjual.

c. Aktivitas listrik dan air untuk dasar pengalokasian dapat berdasarkan jumlah kamar terjual, maka cost driver yang tepat adalah jumlah kamar terjual.

d. Aktivitas pemberian sarapan ditelusuri secara langsung dengan tarif full breakfast sebesar 75.000/kamar. Untuk dasar pengalokasian dapat berdasarkan jumlah tamu yang menginap dan jumlah kamar yang terjual. Tetapi peningkatan biaya pada pemberian makan pagi tergantung pada jumlah tamu yang menginap, maka dijadikan cost driver adalah jumlah tamu menginap.

e. Aktivitas pemasaran dapat dialokasikan berdasarkan jumlah kamar tersedia dan jumlah kamar terjual. Tetapi karena pemasaran dilakukan dengan tujuan untuk menjual semua kamar yang tersedia, maka cost driver yang tepat adalah jumlah kamar tersedia

f. Aktivitas Telepon dan internet untuk dasar pengalokasian dapat berdasarkan jumlah kamar tersedia dan jumlah kamar terjual. Tetapi penggunaan telepon dan internet tidak digunakan atau dipakai hanya pada kamar terjual, maka cost driver yang tepat adalah jumlah kamar tersedia

g. Aktivitas pemeliharaan meliputi pemeliharan gedung dan fasilitas dapat dialokasikan berdasarkan jumlah kamar tersedia dan jumlah kamar terjual. Tetapi pemeliharaan gedung dan fasilitas hotel tidak dilakukan hanya pada kamar terjual, maka cost driver yang tepat adalah jumlah luas bangunan kamar tersedia

h. Aktivitas penyusutan untuk dasar pengalokasian dapat berdasarkan jumlah kamar yang tersedia dan jumlah kamar terjual. Tetapi aktiva tetap dan peralatan resor yang disusutkan digunakan untuk semua kamar yang ada,maka cost driver yang tepat adalah jumlah luas bangunan kamar tersedia.

i. Aktivitas transportasi untuk dasar pengalokasian berdasarkan jumlah tamu yang menginap, maka cost driver yangt tepat adalah jumlah tamu menginap.

j. Aktivitas penggajian untuk cost driver yang tepat adalah jumlah jam kerja.

Pengidentifikasian ini dimaksud untuk mengelompokkan kelompok aktivitas dan cost

driver. Pengelompokan tersebut dapat dilihat pada tabel berikut

Tabel 4.10 Penentuan Cost Driver

\begin{tabular}{|c|c|}
\hline Aktivitas & Cost Driver \\
\hline \multicolumn{2}{|c|}{ Unit-level activity cost } \\
\hline Aktivitas penginapan & Jumlah kamar terjual \\
\hline Aktivitas Listrik dan air & Jumlah kamar terjual \\
\hline Aktivitas laundry & Jumlah kamar terjual \\
\hline Aktivitas penggajian & Jumlah kamar terjual \\
\hline Aktivitas pemberian sarapan & Jumlah tamu menginap \\
\hline Aktivitas transportasi & Jumlah tamu menginap \\
\hline
\end{tabular}


ISSN (Online) : 2503-1635, ISSN (Print): 2088-4656

\begin{tabular}{|c|c|}
\hline Aktivitas & Cost Driver \\
\hline \multicolumn{2}{|c|}{ Batch-related activity cost } \\
\hline Aktivitas Telepon dan Internet & Jumlah kamar tersedia \\
\hline \multicolumn{2}{|c|}{ Product-sustaining activity cost } \\
\hline Aktivitas pemasaran & Jumlah kamar tersedia \\
\hline \multicolumn{2}{|c|}{ Fasilitas-sustaining activity cost } \\
\hline Aktivitas pemeliharaan & Luas lantai \\
\hline Aktivitas penyusutan & Luas lantai \\
\hline
\end{tabular}

Sumber : Data diolah

Berdasarkan tabel 4.10 bahwa terdapat beberapa aktivitas yang memiliki rasio konsumsi dan level aktivitas yang sama sehingga dapat dikelompokkan dalam biaya homogen. Biaya dari aktivitas yang sudah dikelompokkan tersebut dijumlahkan untuk menentukan kelompok-kelompok biaya homogen. Setelah pengelompokkan aktivitas dilakukan maka selanjutnya biaya dari aktivitas yang sudah dikelompokkan tersebut dijumlah. Berikut masing-masing tabel perhitungan per aktivitas cost pool yang sudah dikelompokan adalah sebagai berikut :

Tabel 4.11 Rincian Biaya Per Aktivitas Cost Pool 1

\begin{tabular}{|l|c|r|}
\hline \multicolumn{1}{|c|}{ Aktivitas } & Cost Driver & \multicolumn{1}{c|}{ Biaya (Rp) } \\
\hline $\begin{array}{l}\text { Penginapan : } \\
\text { Room Amenities }\end{array}$ & Jumlah kamar terjual \\
$\begin{array}{l}\text { Superior }:(3424 \times 14404=49.319 .296) \\
\text { Deluxe : }(3932 \times 14404=56.636 .528)\end{array}$ & \\
Junior suite $:(432 \times 14404=6.222 .528)$ & & \\
\hline $\begin{array}{l}\text { Laundry : } \\
\text { Laundry (7788 x 18.500) }\end{array}$ & & \\
\hline listrik dan air & & 112.178 .352 \\
\hline Jumlah & & 464.059 .259 \\
\hline
\end{tabular}

Sumber : Hasil pengolahan data

Berdasarkan tabel 4.11 bahwa biaya aktivitas penginapan dan laundry masing-masing adalah sebesar Rp.112.178.352 dan Rp.416.268.600 sedangkan untuk biaya aktivitas listrik dan air yaitu sebesar Rp. 464.859.259.

Tabel 4.12 Rincian Biaya Per Aktivitas Cost Pool II

\begin{tabular}{|l|r|r|}
\hline Aktivitas & \multicolumn{1}{|c|}{ Cost Driver } & \multicolumn{1}{|l|}{ Biaya (Rp) } \\
\hline Aktivitas pemberian sarapan & Jumlah tamu menginap & \\
Full breakfast & & 408.870 .000 \\
(Rp 35.000 x 11.682 orang) & & 32.414 .190 \\
\hline Aktivitas transportasi & & $\mathbf{4 4 1 . 2 8 4 . 1 9 0 , 0 0}$ \\
\hline Jumlah & &
\end{tabular}

Sumber : Hasil pengolahan data

Berdasarkan tabel 4.12, bahwa aktivitas pemberian sarapan sebesar Rp. 408.870.000, sedangkan untuk biaya aktivitas mobilitas atau transportasi sebesar Rp. 32.414.190

Tabel 4.13 Rincian Biaya Per Aktivitas Cost Pool III

\begin{tabular}{|l|c|r|}
\hline \multicolumn{1}{|c|}{ Aktivitas } & Cost Driver & Biaya (Rp) \\
\hline Aktivitas Telepon dan Internet & Jumlah kamar tersedia & 24.308 .710 \\
\hline Jumlah & & $\mathbf{2 4 . 3 0 8 . 7 1 0}$ \\
\hline
\end{tabular}

Sumber : Hasil pengolahan data 
Tabel 4.14 Rincian Biaya Per Aktivitas Cost Pool IV

\begin{tabular}{|l|l|r|}
\hline \multicolumn{1}{|c|}{ Aktivitas } & Cost Driver & \multicolumn{1}{c|}{ Biaya (Rp) } \\
\hline $\begin{array}{l}\text { Aktivitas Pemasaran } \\
\text { Advertising \& Promotion }\end{array}$ & Jumlah kamar tersedia & 30.000 .000 \\
\hline \multicolumn{1}{|c|}{ Jumlah } & & $\mathbf{3 0 . 0 0 0 . 0 0 0}$ \\
\hline
\end{tabular}

Sumber : Hasil pengolahan data

Tabel 4.15 Rincian Biaya Per Aktivitas Cost Pool V

\begin{tabular}{|l|l|r|}
\hline Aktivitas & Cost Driver & \multicolumn{1}{c|}{ Biaya (Rp) } \\
\hline $\begin{array}{l}\text { Aktivitas Pemeliharaan : } \\
\text { Perbaikan dan Pemeliharaan }\end{array}$ & Luas bangunan & 165.664 .803 \\
\hline $\begin{array}{l}\text { Aktivitas Penyusutan : } \\
\text { Penyusutan Bangunan }\end{array}$ & Luas bangunan & $977,781,353$ \\
\hline \multicolumn{1}{|c|}{ Jumlah } & & $\mathbf{1 . 1 4 3 . 4 4 6 . 1 5 6}$ \\
\hline
\end{tabular}

Sumber : Hasil pengolahan data

Berdasarkan tabel 4.15 bahwa berdasarkan hasil wawancara dengan pihak biaya pemeliharaan sebesar Rp. 165.664.803 dan total biaya penyusutan sebesar Rp. 977,781,353.

Tabel 4.16 Rincian Biaya Per Aktivitas Cost Pool VI

\begin{tabular}{|l|l|c|}
\hline Aktivitas & \multicolumn{1}{|c|}{ Cost Driver } & Biaya (Rp) \\
\hline $\begin{array}{l}\text { Aktivitas Penggajian : } \\
\text { Gaji karyawan } \\
(43 \times 2.105 .615 \times 12)\end{array}$ & Jumlah kamar terjual & \\
\hline \multicolumn{1}{|c|}{ Jumlah } & & 1.086 .497 .340 \\
\hline
\end{tabular}

Sumber : Hasil Pengolahan Data

Aktivitas penggajian yang disajikan pada data tabel 4.16 sebesar Rp. 1.086.497.340 per Tahun dengan jumlah karyawan 43 orang. Dengan posisi General Manager 1 orang, Accounting 3 orang, Engineering 4 orang, Housekeeping 9 orang, Human Resources Development 1 orang, Marketing And Sales Director 3 orang, Food \& Beverage 10 orang, Front Office 5 orang, Security Director 4 orang. Berikut ini adalah tabel pemakaian cost driver adalah sebagai berikut :

Tabel 4.17 Pemakaian Cost Driver

\begin{tabular}{|c|c|c|}
\hline No & Cost Driver & Jumlah \\
\hline 1 & $\begin{array}{l}\text { Jumlah kamar terjual } \\
\text { Superior } \\
\text { Deluxe } \\
\text { Junior Suite }\end{array}$ & $\begin{array}{l}3424 \\
3932 \\
432\end{array}$ \\
\hline & Total & 7788 \\
\hline 2 & $\begin{array}{l}\text { Jumlah tamu menginap } \\
\text { Superior } \\
\text { Deluxe } \\
\text { Junior Suite }\end{array}$ & $\begin{array}{l}5136 \\
5898 \\
648\end{array}$ \\
\hline & Total & 11682 Orang \\
\hline 3 & $\begin{array}{l}\text { Jumlah kamar tersedia } \\
\text { Superior } \\
\text { Deluxe } \\
\text { Junior Suite }\end{array}$ & $\begin{array}{l}30 \\
47 \\
8\end{array}$ \\
\hline & Total & 85 \\
\hline 4 & Jumlah Luas Bangunan & \\
\hline
\end{tabular}




\begin{tabular}{|c|l|lc|}
\hline No & \multicolumn{1}{|c|}{ Cost Driver } & \multicolumn{2}{|c|}{ Jumlah } \\
\hline & Superior & $16 \mathrm{~m}^{2}$ & \\
& Deluxe & $16 \mathrm{~m}^{2}$ & \\
& Junior Suite & $24 \mathrm{~m}^{2}$ & \\
\hline & Total & \multicolumn{2}{|c|}{$\mathbf{~ m}^{2}$} \\
\hline
\end{tabular}

Sumber : Pengolahan Data

4. Menentukan tarif kelompok per unit cost driver

Setelah mengidentifikasi cost driver, langkah selanjutnya menentukan tariff kelompok per unit cost driver karena setiap aktivitasnya memiliki cost driver dengan cara membagi jumlah biaya dengan cost driver. Menurut Hansen and Mowen (2009;134), tarif per unit cost driver dapat dihitung dengan rumus sebagai berikut:

Tarif per unit cost driver $=\frac{\text { Jumlah Akivitas }}{\text { Cost Driver }}$

Berikut ini merupakan penentuan tarif per unit cost driver kamar hotel dengan menggunakan Activity Based Costing System.

Tabel 4.18 Tarif Per Unit Cost Driver

\begin{tabular}{|l|c|c|r|}
\hline \multicolumn{1}{|c|}{ Cost Pool } & $\begin{array}{c}\text { Jumlah Aktivitas } \\
\text { (Rp) }\end{array}$ & Cost Driver & $\begin{array}{c}\text { Tarif Per Unit } \\
\text { (Rp) }\end{array}$ \\
\hline Cost pool I & $721.115 .611,00$ & 7788 & $92.593,17$ \\
\hline Cost pool II & $441.284 .190,00$ & 11682 & $37.774,71$ \\
\hline Cost pool III & $24.308 .710,00$ & 85 & $285.984,82$ \\
\hline Cost pool IV & $30.000 .000,00$ & 85 & $352.941,18$ \\
\hline Cost pool V & $1.143 .446 .156,30$ & 297 & $3.849 .987,06$ \\
\hline Cost pool VI & $1.086 .497 .340,00$ & 7788 & $139.509,16$ \\
\hline
\end{tabular}

Sumber : Hasil Pengolahan Data

5. Membebankan biaya ke produk dengan menggunakan tarif cost driverdan ukuran aktivitas.

Dalam tahap ini, menurut Hansen and Mowen (2009; 138), biaya aktivitas dibebankan ke produk berdasarkan konsumsi masing-masing aktivitas produk. Pembebanan biaya overhead dari tiap aktivitas ke setiap kamar dihitung dengan rumus sebagai berikut :

BOP yang dibebankan $=$ Tarif/Unit $\mathrm{x}$ Cost Driver yang Dipilih

Dengan mengetahui BOP (biaya overhead pabrik) yang dibebankan pada masing-masing produk, maka dapat dihitung tarif per hotel. Berikut ini tarif hotel untuk masing-masing tipe kamar :

Tabel 4.19 Tarif Sewa Kamar Hotel Zenith Untuk Superior

\begin{tabular}{|l|r|}
\hline \multicolumn{1}{|c|}{ Aktivitas } & Tarif Per Unit (Rp.) \\
\hline Aktivitas Penginapan & $14,404.00$ \\
\hline Aktivitas laundry & $16,450.00$ \\
\hline Aktivitas Listrik dan Air & $55,000.00$ \\
\hline Aktivitas Sarapan Pagi & $35,000.00$ \\
\hline Aktivitas Telepon dan Air & $100,000.00$ \\
\hline Tarif Kamar Superior & $\mathbf{2 2 0 , 8 5 4 . 0 0}$ \\
\hline
\end{tabular}

Sumber : Hasil Pengolahan Data

Berdasarkan tabel 4.19 terdapat beberapa aktivitas-aktivitas dari data yang diperoleh yang terdiri dari aktivitas penginapan, laundry, listrik dan air, sarapan pagi, telepon dan air. Dari aktvitas-aktivitas tersebut diperoleh tarif untuk superior sebesar Rp. 220,854.00. 
Tabel 4.20 Tarif Sewa Kamar Hotel Zenith Untuk Deluxe

\begin{tabular}{|l|r|}
\hline Aktivitas & Tarif Per Unit (Rp.) \\
\hline Aktivitas Penginapan & $14,404.00$ \\
\hline Aktivitas laundry & $18,500.00$ \\
\hline Aktivitas Listrik dan Air & $55,000.00$ \\
\hline Aktivitas Sarapan Pagi & $35,000.00$ \\
\hline Aktivitas Telepon dan Internet & $180,000.00$ \\
\hline Tarif Kamar Deluxe & $\mathbf{3 0 2 , 9 0 4 . 0 0}$ \\
\hline
\end{tabular}

Sumber : Hasil Pengolahan Data

Berdasarkan tabel 4.20 bahwa biaya aktivitas-aktivitas dari data yang diperoleh yang terdiri dari aktivitas penginapan, laundry, listrik dan air, sarapan pagi, telepon dan air. Dari aktvitas-aktivitas tersebut diperoleh tarif untuk deluxe sebesar Rp. 302,904.00.

Tabel 4.21 Tarif Sewa Kamar Hotel Zenith Untuk Junior Suite

\begin{tabular}{|l|r|}
\hline \multicolumn{1}{|c|}{ Aktivitas } & Tarif Per Unit (Rp.) \\
\hline Aktivitas Penginapan & $14,404.00$ \\
\hline Aktivitas laundry & $18,500.00$ \\
\hline Aktivitas Listrik dan Air & $75,000.00$ \\
\hline Aktivitas Sarapan Pagi & $35,000.00$ \\
\hline Aktivitas Telepon dan Internet & $280,000.00$ \\
\hline Tarif Kamar Junior Suite & $\mathbf{4 2 2 , 9 0 4 . 0 0}$ \\
\hline
\end{tabular}

Sumber : Hasil Pengolahan Data

Berdasarkan tabel 4.21 bahwa biaya aktivitas-aktivitas dari data yang diperoleh yang terdiri dari aktivitas penginapan, laundry, listrik dan air, sarapan pagi, telepon dan air. Dari aktvitas-aktivitas tersebut diperoleh tarif untuk junior suite sebesar Rp. 422,904.00.

\subsubsection{Perbedaan Tarif Sewa Kamar Antara Perhitungan Yang Dilakukan Perusahaan}

Dengan Metode Tradisional dan Activity Based Costing

Hasil perhitungan tarif sewa kamar dengan metode tradisional dan $\mathrm{ABC}$ memiliki perbedaan. Perbedaan tersebut dapat dilihat pada tabel 4.22 berikut :

Tabel 4.22 Perbedaan Tarif Sewa Kamar Antara Perhitungan Yang Dilakukan Perusahaan Dengan Metode Tradisional dan Activity Based Costing

\begin{tabular}{|l|c|c|c|l|}
\hline \multicolumn{1}{|c|}{ Tipe kamar } & $\begin{array}{c}\text { Perhitungan } \\
\text { tradisional } \\
\text { (Rp) }\end{array}$ & $\begin{array}{c}\text { Activity } \\
\text { based costing } \\
\text { (Rp) }\end{array}$ & $\begin{array}{c}\text { Selisih } \\
(\mathbf{R p )}\end{array}$ & $\begin{array}{c}\text { Keterang } \\
\text { an }\end{array}$ \\
\hline Superior & $300.000,00$ & $220.854,00$ & $79,146.00$ & Overcosted \\
\hline Deluxe & $350.000,00$ & $302.904,00$ & $47,096.00$ & Overcosted \\
\hline Junior Suite & $550.000,00$ & $422.904,00$ & $127,096.00$ & Overcosted \\
\hline
\end{tabular}

Sumber: Hasil Pengolahan Data

Berdasarkan tabel 4.22 bahwa tarif kamar dengan menggunakan metode tradisional yaitu untuk jenis kamar superior sebesar Rp.300.000,00, untuk deluxe sebesar Rp.350.000,00, dan untuk junior suite sebesar Rp.550.000,00. Sedangkan tarif kamar dengan menggunakan metode Activity Based Costing menghasilkan tarif untuk jenis kamar superior sebesar Rp.220.854,00, untuk deluxe sebesar Rp. 302.904,00, dan untuk junior suite sebesar Rp.422.904,00. Dari hasil yang diperoleh terdapat selisih perhitungan antara metode tradisional dan metode ABC dengan selisih masing-masing yaitu untuk jenis kamar superior sebesar Rp. 79,146.00, untuk deluxe sebesar Rp.47,096.00, dan untuk junior suite sebesar Rp.127,096.00. 


\subsection{Pembahasan}

Evaluasi penentuan tarif kamar dengan menggunakan metode ABC System. Sistem informasi biaya yang berorientasi pada penyediaan informasi lengkap tentang aktivitas untuk memungkinkan personel perusahaan melakukan pengolahan terhadap aktivitas. Sistem informasi ini menggunakan aktivitas sebagai basis serta pengurangan biaya dan penentuan secara akurat cost produk/jasa sebagai tujuan. Pengelolaan aktivitas ditujukan untuk mengerahkan dan mengarahkan seluruh aktivitas organisasi ke penyediaan produk/jasa bagi kepentingan pemuasan kebutuhan customer.

Hasil yang didapat dari perhitungan tarif sewa kamar dengan menggunakan metode $\mathrm{ABC}$ System untuk jenis kamar Superior sebesar Rp.220.854,00. Untuk kamar Deluxe sebesar Rp.302.904,00. Dan untuk Junior Suite sebesar Rp.422.904,00. Dari hasil yang diperoleh pada metode ABC System memberikan hasil perhitungan lebih rendah dari tarif yang telah ditetapkan oleh perusahaan dengan selisih harga untuk jenis kamar Superior sebesar Rp.79,146.00, untuk jenis kamar Deluxe sebesar Rp.47,096.00 dan Junior Suite sebesar Rp.127,096.00.

Terjadinya selisih tarif sewa dikarenakan pada metode Activity Based Costing biaya overhead pada masing-masing produk dibebankan pada banyak cost driver. Sehingga dalam metode Activity Based Costing mampu mengalokasikan biaya aktivitas ke setiap jenis kamar secara tepat berdasarkan konsumsi masing-masing aktivitas.

\subsection{Evaluasi Penentuan Tarif Kamar Hotel Dengan Menerapkan Metode Activity Based Costing.}

Evaluasi penentuan tarif dengan menerapkan metode ABC System merupakan hal yang harus dilakukan perusahaan dalam mengevaluasi tarif sebagai dasar perencanaan target profit (Keuntungan) secara tepat. Sehingga hasil tarif sesuai kondisi organisasi/perusahaan dan ekonomi konsumen. Penerapan metode ABC System merupakan inovasi yang salah satunya adalah untuk mengurangi aktivitas yang tidak memberikan nilai tambah, menambah nilai tambah pada produk yang akan dihasilkan dan mengeliminasi aktivitas-aktivitas yang tidak sesuai atau tidak menciptakan nilai tambah.

Evaluasi penentuan tarif kamar dengan menerapkan metode Activity Based Costing. Penentuan tarif dengan metode tradisional memiliki kelemahan diantaranya adanya ketidakakuratan perusahaan dalam pembebanan biaya, disebabkan karena perusahaan tidak melakukan perhitungan biaya-biaya yang terjadi pada saat penentuan tarif kamar hanya menghitung secara tradisionl dan membandingkan dengan sesama hotel sejenis. Sehingga peneliti melakukan penelitian dengan metode Activity Based Costing. Activity Based Costing merupakan sistem perhitungan biaya yang menghitung semua biaya yang timbul dari aktivitasaktivitas yang terjadi dalam perusahaan (hotel ) sesuai dengan standar yang digunakan.

Activity Based Costing memberikan hasil perhitungan tarif yang lebih rendah untuk jenis kamar superior, deluxe, dan junior suite berdasarkan perhitungan yang dapat dilihat pada tabel 4.22. Sehingga terdapat selisih untuk jenis kamar Superior sebesar Rp.79,146.00, untuk jenis kamar Deluxe sebesar Rp.47,096.00 dan Junior Suite sebesar Rp.127,096.00. Hal tersebut, dipengaruhi oleh perhitungan aktivitas yang tidak hanya terbatas pada aspek produksi. Namun aspek desain dan dukungan logistik yang menimbulkan aktivitas biaya menjadi variabel perhitungan sebagai cost driver nya. Hal ini sejalan dengan Dunia dkk. (2012) dalam bukunya yang berjudul "Akuntansi Biaya, Edisi ketiga". 


\subsection{Kesimpulan}

\section{KESIMPULAN DAN SARAN}

Berdasarkan hasil penelitian dan pembahasan dapat disimpulkan Perhitungan tarif sewa kamar dengan menggunakan metode Activity Based Costing System dilakukan dengan dua tahap. Tahap pertama biaya ditelusuri ke aktivitas yang menimbulkan biaya dan kemudian tahap kedua membebankan biaya aktivitas ke produk. Dari perhitungan tarif sewa kamar menggunakan metode Activity Based Costing diketahui besarnya tarif untuk jenis kamar Superior sebesar Rp.220.854,00. Untuk kamar Deluxe sebesar Rp. 302.904,00. Dan untuk Junior Suite sebesar Rp. 422.904,00. Terdapat perbedaan antara tarif yang ditetapkan oleh perusahaan dan perhitungan dengan menggunakan metode Activity Based Costing. Dan perhitungan dengan menggunakan metode Activity Based Costing terdapat perbedaan antara perhitungan tarif yang ditetapkan oleh perusahaan dan perhitungan tarif dengan menggunakan metode Activity Based Costing yaitu pada metode Activity Based Costing memberikan hasil yang lebih rendah dengan selisih untuk jenis kamar Superior sebesar Rp. 79,146.00, untuk jenis kamar Deluxe sebesar Rp. 47,096.00 dan Junior Suite sebesar Rp.127,096.00.

\subsection{Saran}

Berdasarkan kesimpulan diatas maka, saran yang dapat diberikan penulis adalah perusahaan sebaiknya pihak manajemen hotel mulai mempertimbangkan dan mengadakan penelitian lebih lanjut mengenai metode Activity Based Costing untuk menghitung cost kamar, agar dapat memperoleh informasi tarif kamar yang lebih tepat dan baik. dan peneliti selanjutnya agar meneliti ditempat atau perusahaan jasa yang bisa memberikan informasi biaya yang lebih detail dan yang telah melakukan pemisahan biaya berdasarkan aktivitas agar mempermudah dalam melakukan perhitungan metode Activity Based Costing.

\section{DAFTAR PUSTAKA}

Ardino, 2017. Analisis penerapan metode activity based costing dalam menentukan sewa kamar penginapan (studi pada wakatobi dive resort onemoba'a tomia). Skripsi. Fakultas Ekonomi Universitas Halu Oleo Kendari.

Blocher, J., dkk. 2011. Manajemen Biaya. (Terjemahan David Wijaya). Jakarta: Salemba Empat. (Edisi asli diterbitkan tahun 2010 oleh McGraw-Hill 1221 Avenue of The Americas New York).

Bustami, Bastian dan Nurlela. 2010. Akuntansi Biaya. Edisi 4. Jakarta; Mitrawakanamedia.

Carter, William K. 2012. Akuntansi Biaya. Buku 1. Edisi 14. Jakarta: Salemba Empat.

Cindrawati, Septya Dewi, Zulkrom, M, Zahroh. 2014. Penerapan Activity Based Costing SystemSebagai Dasar Menentukan Harga Pokok Kamar Hotel (Studi Kasus Pada Hotel Pelangi Malang Periode 2012). Jurnal Administrasi Bisnis (JAB). Vol 8 number 9. Edisi Maret. Hlm 1-10. (diakses 0202 2019).

Dunia, Firdaus Ahman dan Wasilah, Abdullah. 2012. Akuntansi Biaya. Edisi ketiga. Jakarta: Penerbit Salemba Empat.

Garrison, Norren, dan Brewer. 2013. Akuntansi Manajerial. Jakarta: Salemba Empat.

Hansen, M.dan Mowen. 2012. Manajemen Biaya. Jakarta. Salemba Empat.

Hansen, Don R. Maryanne M Mowen 2006. Akuntansi manajemen. Diterjemahkan oleh Dewi Fitriasari dan Deny Kwary. Edisi 7 Jakarta : Salemba Empat.

Hansen, Don R. Maryanne M Mowen 2013. Akuntansi Manajerial. Jakarta: Salemba Empat Iklina, Junita. 2016. Analisis penerapan Activity Based Costing System dalam menentukan harga pokok kamar hotel studi kasus dihotel UNY Yogyakarta. Skripsi. Fakultas Ekonomi Universitas Sanata Dharma Yogyakarta. 
ISSN (Online) : 2503-1635, ISSN (Print): 2088-4656

Maulana, Helny, Ardi, Dwiatmanto. 2014. Analisis Activity Based Costing System (ABC System) sebagai dasar menentukan harga pokok kamar hotel (studi kasus pada hotel selecta Kota Baru tahun 2014). Jurnal Administrasi Bisnis (JAB). Vol 30, number 1. Edisi Januari 2016.

Mursyidi. 2014. Akuntansi Biaya. Bandung. Aditama.

Mulyadi. 2014. Activity Based Costing System. Edisi 6. Yogyakarta: Graha Ilmu.

Mulyadi. 2015. Akuntansi Biaya. Yogyakarta: Graha Ilmu.

Rudianto. 2013. AkuntansiManajemen informasi untuk pengambilan keputusan strategi. Jakarta: Erlangga.

Sanusi Anwar, 2014; Metodologi penelitian bisnis, Cetakan keempat, Salemba Empat. Jakarta.

Sari, Vivi Parita. 2017. Penerapan metode Activity Based Costing System dalam penentukan harga pokok kamar hotel pada Hotel Grand Kartika Pontianak.Jurnal FinAcc.Vol1 number 9. Januari 2017. (diakses0202 2019).

Siregar, dkk 2013. Akuntansi Manajemen. Jakarta. Salemba.

Sugiyono. 2013. Metode Penelitian Kuantitatif, Kualitatif dan $R \& D$. Penerbit Alfabeta:Bandung. Supriyono. 2010. Akuntansi Biaya. Yogyakarta: Penerbit BPFE.

Surat Keputusan Menparpostel No. KM.37/PE.040/MPPT.86: Tentang Peraturan Usaha dan Penggolongan Hotel. Bab 1 Pasal 1 ayat (b).

Warindrani, ArmilaKrisna. 2006. Akuntansi Manajemen. Edisi Pertama, Cetakan Pertama. Grahallmu, Yogyakarta. 